\title{
Two en bloc circumferential endoscopic resections of synchronous esophageal neoplasms: a reality even in the West
}

A 50-year-old man with oropharynx cancer (T3N0M0) underwent upper gastrointestinal endoscopy to search for synchronous lesions. Endoscopic examination identified two synchronous extensive flat lesions (T0-IIb) in the esophagus: lesion A - a 5-cm lesion, occupying 75\% of the circumference, located between 16 and $21 \mathrm{~cm}$ from the incisors; lesion B - a 5-cm circumferential lesion, located between 26 and $31 \mathrm{~cm}$ from the incisors. The intrapapillary capillary loop classification was suggestive of type V3. Endoscopic ultrasound revealed neither submucosal invasion nor locoregional lymphadenopathies. Following multidisciplinary evaluation, endoscopic submucosal dissection (ESD) was planned ( Video 1).

On account of the distance between the lesions, separate circumferential excision assisted by endoscopic submucosal tunnel dissection (ESTD) was performed using a FlushKnife (Fujifilm Corp., Tokyo, Japan). Circular incisions were completed at the anal and oral margins, and ESTD was accomplished from the oral to the anal side creating two submucosal tunnels in the proximal lesion and three submucosal tunnels in the distal lesion (larger esophageal lumen) (> Fig.1). Submucosal dissection was completed and separate en bloc resections were achieved ( $>$ Fig. 2, > Fig. 3).

The procedure took 270 minutes and the patient was discharged 48 hours after the procedure under oral prednisolone. Pathological analysis revealed a well-differentiated squamous cell neoplasia (SCC), without lymphovascular invasion; the tumor was intramucosal and resection was complete in lesion A but submucosal invasion with positive vertical margins were present in lesion B. After multidisciplinary evaluation, chemoradiotherapy for both esophageal and oropharyngeal neoplasms was per-

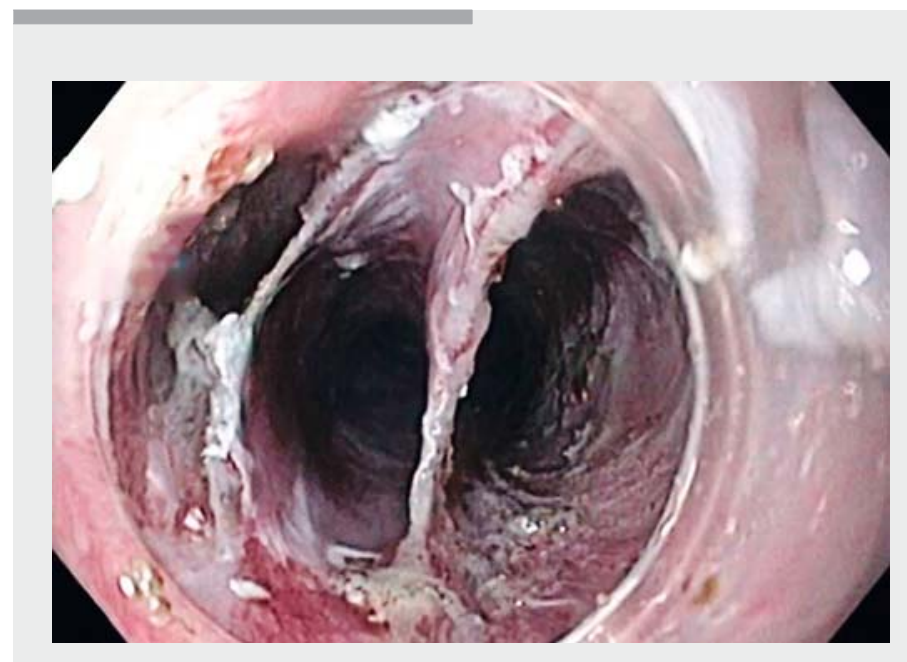

Video 1 Endoscopic submucosal tunnel dissection for the treatment of synchronous esophageal neoplasms.

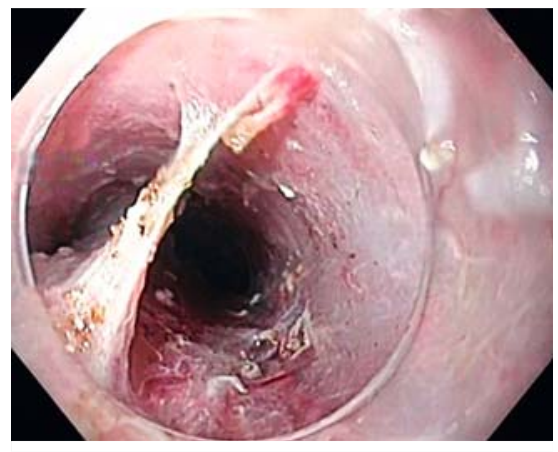

- Fig. 1 Submucosal tunnels were created covering the whole esophageal lumen.

formed. Three months later, the patient refused endoscopic re-evaluation but there was no unequivocal dysphagia.

ESD is a well-established treatment for superficial esophageal SCC. However, for large circumferential lesions, ESTD has a more rapid dissection speed and higher R0 resection rate compared with conventional ESD [1-2]. Although widely performed in Asia, only a few cases have been described at Western centers [3-

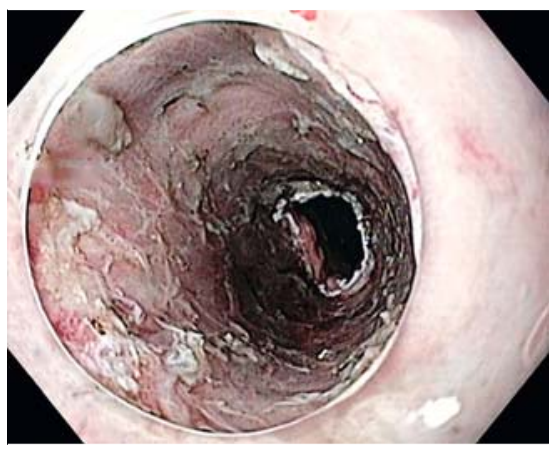

Fig. 2 Ulcers were reassessed without muscular injury or bleeding.

4]. To the best of our knowledge, this is the first report of ESTD for two synchronous circumferential SCCs in a Western center.

Endoscopy_UCTN_Code_TTT_1AO_2AG

Competing interests

None 

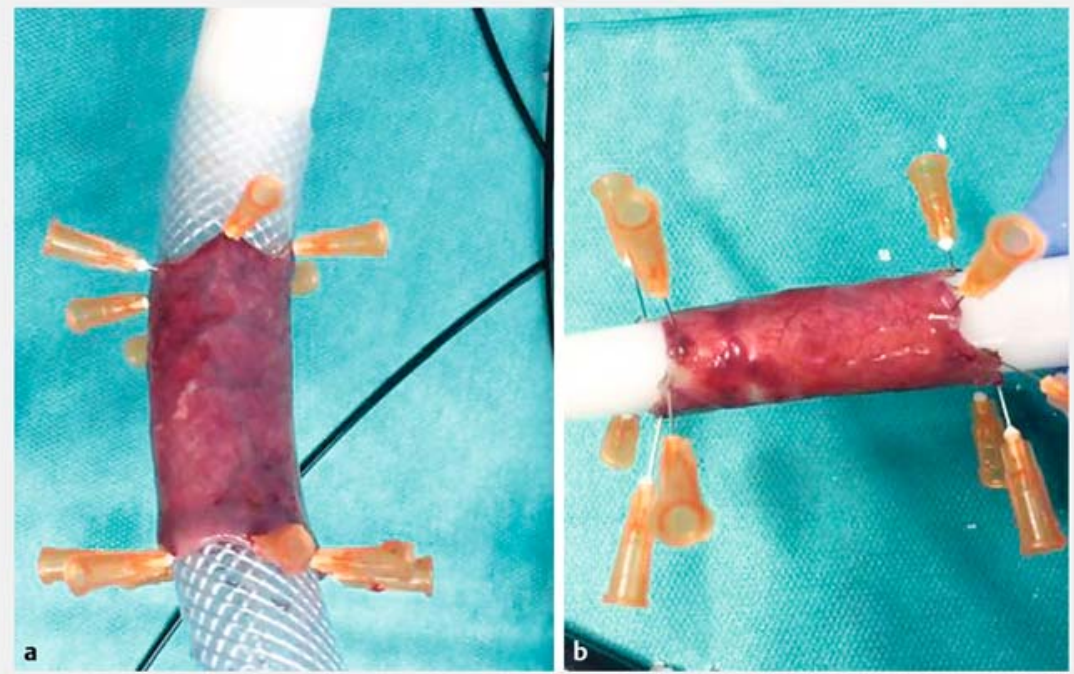

- Fig.3 Complete circumferential en bloc resection of esophageal lesions. a The distal lesion. b The proximal lesion.

The authors

\section{Catarina Félix ${ }^{1}$, lala Pereira ${ }^{1}$, Susana}

Marques ${ }^{1}$, Pedro Barreiro' ${ }^{1}$, Miguel Bispo ${ }^{2}$,

\section{Cristina Chagas ${ }^{1}$}

1 Serviço de Gastrenterologia, Centro Hospitalar de Lisboa Ocidental, Lisbon, Portugal

2 Gastrenterologia, Fundação Champalimaud, Lisbon, Portugal

\section{Corresponding author}

\section{Catarina Félix, MD}

Serviço de Gastrenterologia, Centro

Hospitalar de Lisboa Ocidental EPE, Hospital de Egas Moniz Rua da Junqueira 126, Lisboa 1349-019, Portugal

Fax: +351-21-0432430

sfelixcatarina@gmail.com

\section{References}

[1] Zhai YQ, Li HK, Linghi EQ. Endoscopic submucosal tunnel dissection for large superficial esophageal squamous cell neoplasms. World J Gastroenterol 2016; 22: 435-445

[2] Zhang W, Zhai $\mathrm{Y}$, Chai $\mathrm{N}$ et al. Endoscopic submucosal tunnel dissection and endoscopic submucosal dissection for large superficial esophageal squamous cell neoplasm: efficacy and safety study to guide future practice. Surg Endosc 2018; 32: 2814-2821

[3] Pioche M, Mais L, Guillaud O et al. Endoscopic submucosal tunnel dissection for large esophageal neoplastic lesions. Endoscopy 2013; 45: $1032-1034$

[4] Andalib I, Dawod E, Saumoy M et al. Endoscopic submucosal tunnel dissection for early squamous cell carcinoma of the esophagus. Endoscopy 2018; 50: E88 - E89

\section{Bibliography}

DOI https://doi.org/10.1055/a-0820-0906

Published online: 18.1.2019

Endoscopy 2019; 51: E65-E66

(c) Georg Thieme Verlag KG

Stuttgart · New York

ISSN 0013-726X

\section{ENDOSCOPY E-VIDEOS}

https://eref.thieme.de/e-videos

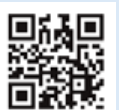

Endoscopy E-Videos is a free access online section, reporting on interesting cases and new

techniques in gastroenterological endoscopy. All papers include a high quality video and all contributions are freely accessible online.

This section has its own submission website at

https://mc.manuscriptcentral.com/e-videos 